\title{
The Evolution Before the Revolution
}

\author{
Brenda Darden Wilkerson \\ President \& CEO of AnitaB.org
}

\begin{abstract}
As founder of the original Computer Science for All (CS4All) initiative in the Chicago Public Schools, Brenda Darden Wilkerson set the standard for integrating computer science classes into the curriculum for every student. Now, she's leading the charge to break down barriers for women and members of other underrepresented minorities in the tech industry. She argues that, while many administrators and community leaders see CS4All as merely a key component of a new core curriculum, CS educators are actually sowing the seeds of the next workplace revolution. In this inspirational keynote, Brenda will share the ways that educators on the front lines of this inclusive movement can expect to reap the fruits of their labor - not just professionally, but personally - in surprising ways. And she'll spotlight the historic role of women, and people of color, in technology and computer science, offering examples that will better allow us all to reclaim our rightful seats at the table.
\end{abstract}

\section{Keywords}

Computer Science for All; Computing Education

\section{ACM Reference format:}

Brenda Darden Wilkerson. 2018. The Evolution Before the Revolution. In SIGCSE'18: The 49th ACM Technical Symposium on Computer Science Education, Feb. 21-24, 2018, Baltimore, MD, USA. ACM, NY, NY, USA, 1 pages. DOI: https://doi.org/10.1145/3159450.3166085

\section{BIOGRAPHY}

Brenda Darden Wilkerson is an advocate for access, opportunity, and social justice for underrepresented communities in technology. She currently serves as the President and CEO of AnitaB.org, an organization working to shape public opinion about issues of critical importance to women technologists in academia, industry, and government. She founded the original Computer Science for All program, building computer science classes into the curriculum for every student in the Chicago Public Schools, and serving as the inspiration for the Obama administration's national CS4All initiatives.

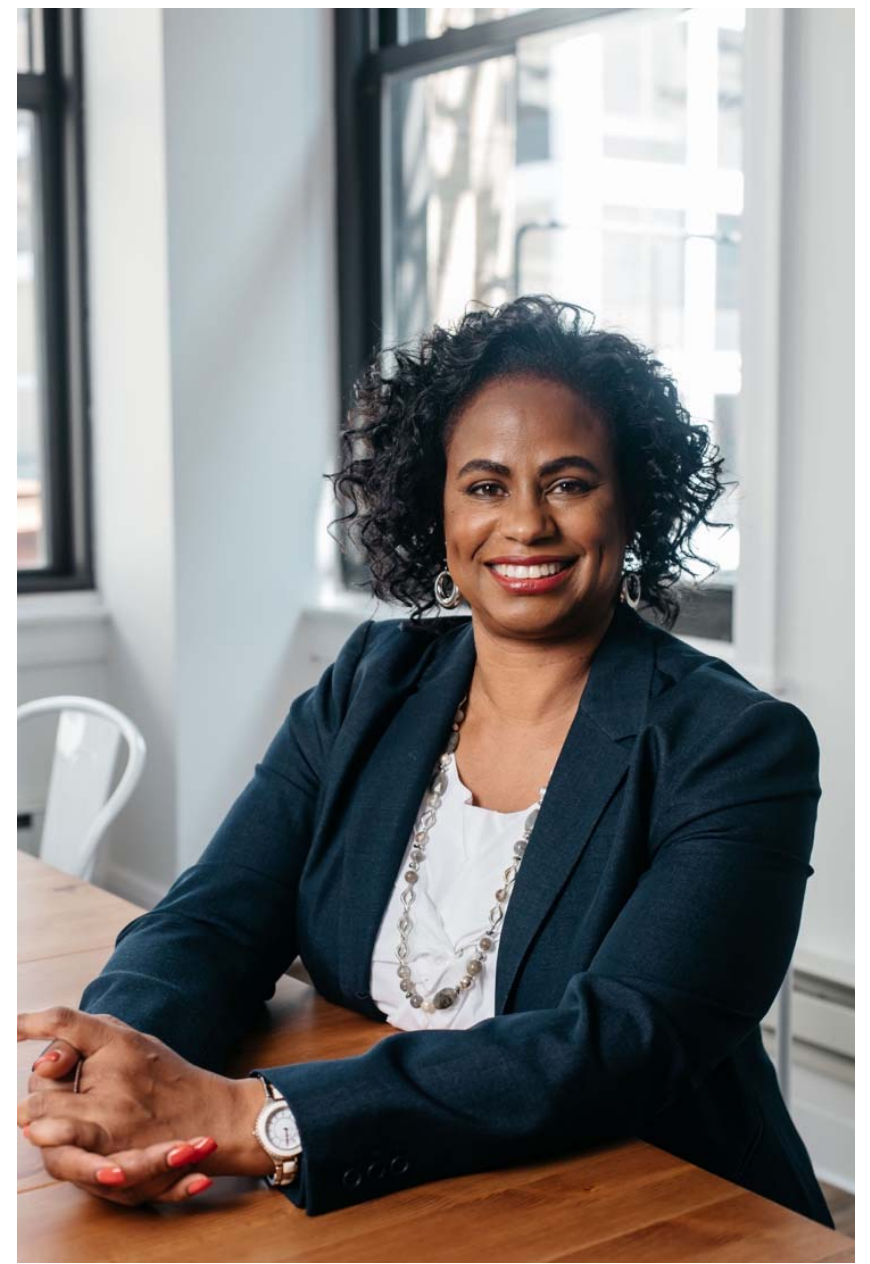

Permission to make digital or hard copies of part or all of this work for personal or classroom use is granted without fee provided that copies are not made or distributed for profit or commercial advantage and that copies bear this notice and the full citation on the first page. Copyrights for third-party components of this work must be honored. For all other uses, contact the Owner/Author.

SIGCSE '18, February 21-24, 2018, Baltimore, MD, USA

(C) 2018 Copyright is held by the owner/author(s).

ACM ISBN 978-1-4503-5103-4/18/02

DOI: https://doi.org/10.1145/3159450.3166085 